\title{
THE ROLE OF MARKETING IN SOLVING PROBLEMS OF THE SOCIAL AND THE LABOUR SPHERE OF RURAL AREAS
}

\author{
Tatyana Diadyk, Viktoria Khurdei, Volodymyr Pysarenko, Yanina Tagiltseva \\ Poltava State Agrarian Academy, Ukraine
}

\begin{abstract}
The article deals with the study of the theoretical essence of "Marketing 3.0", the necessity and the efficiency of its usage for the regulation of a rural employment and unemployment reduction. The economic activity of population according to age groups and residence, the level of registered unemployment in rural areas and cities as well as the dynamics of average monthly earnings on the basic kinds of economic activities in Ukraine have been analysed aiming to estimate the mechanism of labour market performance in rural areas. The main reasons of youth unemployment in rural areas have been identified. The activities of employment agencies have been analysed. It has been proved that marketing 3.0 is a strategic future of the agrarian business in the context of improving the condition in the social and labour sphere.
\end{abstract}

Keywords: marketing 3.0, marketing research, labour market, social and labour relations, rural areas, employment, unemployment

DOI: 10.17512/znpcz.2016.1.11

\section{The statement of the problem}

One of the current problems is undervaluation of the negative impact of challenging economic situation on the solution of social problems. The social and labour sphere of rural areas in Ukraine (which is considered as an agrarian country according to the international division of labour) is of prime importance. However, the sphere has lately obtained a number of negative characteristics that caused a challenge in the labour market, i.e. the aggravation of unemployment, the disinclination of youth to be employed in the agrarian sphere, the problems of women's job placement, the deterioration of working conditions, the violation of core working hours, the cutting of real wages and the guarantee of fair ones, etc.

Problems have always arisen in different societies. Everyone has a certain social status, temper, preferences, tastes, needs as well as a will power. However, to realize a labour ability, to reproduce a labour power, to achieve self-esteem and to be settled in a society is not only the necessity, but the need of every civil human at any time. Labour means not only to receive a financial gain for satisfying needs, but it is a need of any normal healthy organism. Labour as an element of culture and socialization of people depends heavily on the information: concerning profession, the level and rate of wages, working conditions, career development, etc. 
Hence, much attention should be paid to both labour resources capacity and social problems of modern labour market performance in rural areas. Taking into account existing informational deficiency in the rural population concerning the dynamics and tendencies of labour market development, one of the important directions in the sphere of monitoring of social and labour relations is the introduction of marketing research.

\section{The analysis of the latest research and publications}

The study of theoretical and practical problems of employment, unemployment, personal fulfillment, the problems of advance in the educational level, the professional and territorial mobility of labour resources are considered in the research papers by V. Adamchuk, I. Bahrova, O. Bohutskyi, O. Hrishnova, V. Horbunov, V. Diiesperov, H. Dmytrenko, M. Dolishnii, S. Zlupko, N. Kopach, V. Onikiienko, I. Petrova, T. Tokarskyi and others. However, the problem of labour marketing, particularly in rural areas, hasn't been studied abundantly yet. The theoretical issues of marketing in the labour and employment sphere are considered in the scientific papers by E. Bohdanova, D. Bohynia, V. Hordyn, L. Hnezdylova, S. Lehominova, A. Leonov, O. Kovbasko, M. Tsukhan.

Marketing research of the labour market and the introduction of "Marketing 3.0" (from goods to consumers and then to a human nature) is a new direction in the sector of employment.

Nowadays the problem of employment of the rural population is characterized by its particular significance and a social severity that is intensified by tendencies towards the increasing of a widespread unemployment and the irrational labour service in bisuness and in organizations of different forms of ownership (Онікієнко 2013, p. 456).

Marketing research of the labour market requires not only the fundamental analysis of factors of micro- and macroenvironment in which this market functions, but well-grounded assessments of the development of marketing environment of the labour market, while the introduction of "Marketing 3.0" in the labour market will enable to focus on a human in marketing and to increase marketing contribution to the solution of social and labour problems as well as to support an appropriate balance between job vacancies and redundant workers that is one of the main macroeconomic problems, and that's why it requires timely study of the experience of a successful labour market performance gained by the countries with market economy (Легомінова, Маркетинг ринку праці (методологія досліджень) [електронний ресурс] - Режим доступу: http://www.lib.ua-ru.net/ diss/cont/26468.html; Brzozowska, Kalinichenko, Kabus 2015, pp. 10-14).

The present stage of the development of the world society is characterized by remarketing and transition to the marketing that focuses on a human, his/her values and nature. "Marketing 0.3 " is a personal involvement and a voluntary wish to help. In the labour sphere "Marketing 0.3" enables an employee to create the labour force, taking into account economic conditions of the labour market and its laws (Котлер, Картаджайя, Сетиаван 2012, р. 240). 
Personal marketing can be defined as the formation of a positive image as a highly-qualified, high-toned, hard-working person who is able to work efficiently in a team. It stipulates formation of the labour force in terms of providing of a high level of its quality and competitiveness, distribution of a positive information in the labour market ( Ковбаско 2012, pp. 89-90). In the process of personal marketing it is necessary to identify the level of labour market demand of a certain level of quality and the price range. However, a great demand for certain jobs and qualifications doesn't always guarantee a high payment and a successful career. It is necessary to take into consideration possible changes in the labour market influenced by such tendencies as the economic globalization and integration processes in the world, the economic restructuring, the development of certain spheres of business and the decline of others ( Грішнова 2007, p.559).

\section{The objective of the research}

The article is aimed at estimatng the mechanism of labour market performance in rural areas, particularly the efficiency of "Marketing $0.3^{3}$ ' in the social and labour sphere.

\section{The main part of the research}

The pressing problems in rural areas of Ukraine are unemployment and poverty, decline of the social sphere, a low level of culture, physical burden as well as withering-away of the rural area. The most part of unemployed population (that is able and unable to work) doesn't make sense or has no the opportunity to improve the economic and social condition of the rural area that, in future, disables an efficient development of rural areas. Today we can state the fact that the social sphere of rural areas which (as any other sphere) is aimed to reproduce human resources lost in the process of production still has been decreasing its status. The enhancement of a social disparity leads to devastating consequences, as the economy of agriculture is unable to function efficiently neither as a production nor as a consumption system. In most cases, the level of profitability of agrarian business activities doesn't guarantee more extensive reproduction.

The aim of marketing research of the social and labour sphere in rural areas should be not only the research of the dynamics of demand and supply of the labour force taking into account perspectives of labour market development in the industry of agribusiness, but monitoring of current characteristics of the product "labour force" in order to satisfy requirements of the customer-entrepreneur who buys it.

Marketing research should be focused on the regular analysis of changes in requirements of employees and employers. The latter ones want to buy a competitive labour force. Job applicants hope for fair wages and comfortable working conditions. The role of personal marketing is underestimated in the labour market. This is because most rural population is not familiar with the essence of this term. Relatively low level of awareness of the rural population concerning the job opportunity stipulates a poor competitiveness of its labour force in comparison 
with city dwellers. It should be mentioned that even such a powerful marketing tool as the Internet is rarely used by the rural population that either doesn't have access to it or doesn't have skills in searching necessary information. Of course, a city dweller has more chances to find employment or additional earnings by means of the Internet staying at home or in a café (where in each one there is Wi-Fi zone). From our point of view, the main reason of non-use of the Net by the rural population searching a job is subjective. First of all, it is a psychological distrust of the Net (especially, of the older generation) as well as inability of using it and, as a result, appealing to the lack of time and the absence of necessity in the Internet.

Negative tendencies in the labour market of rural areas are caused by the fact that the rural population size constantly decreases in Ukraine, particularly, on account of the decline in natural growth. Besides, it is connected with migration of the rural population (mostly youth) to cities. According to the data, the size of economically active rural population is almost a third of from urban one and, in absolute terms, comes to $5,85 \mathrm{mln}$. at the age of $15-70$ and $5,48 \mathrm{mln}$. of working age (table 1).

Table 1. The economic activity of population according to place of residence in Ukraine, 2014

\begin{tabular}{|c|c|c|c|c|c|}
\hline Indicators & $\begin{array}{c}\text { Unit of } \\
\text { measurement }\end{array}$ & $\begin{array}{c}\text { All } \\
\text { population }\end{array}$ & $\begin{array}{c}\text { Urban } \\
\text { settlement }\end{array}$ & $\begin{array}{c}\text { Rural } \\
\text { area }\end{array}$ &,+- \\
\hline $\begin{array}{l}\text { Economically } \\
\text { active population }\end{array}$ & \multirow{3}{*}{$\begin{array}{l}\text { thousand of } \\
\text { people }\end{array}$} & \multirow[b]{2}{*}{$19,920.9$} & \multirow[b]{2}{*}{$14,070.3$} & \multirow[b]{2}{*}{$5,850.6$} & \multirow[b]{2}{*}{$-8,219.7$} \\
\hline at the age of $15-70$ & & & & & \\
\hline of working age & & $19,035.2$ & $13,552.7$ & $5,482.5$ & $-8,070.2$ \\
\hline $\begin{array}{l}\text { The level of } \\
\text { economic activity } \\
\text { of population }\end{array}$ & \multirow{3}{*}{$\begin{array}{c}\text { as } \% \text { to } \\
\text { population of } \\
\text { the } \\
\text { appropriate } \\
\text { age group }\end{array}$} & \multirow[b]{2}{*}{62.4} & \multirow[b]{2}{*}{62.6} & \multirow[b]{2}{*}{61.8} & \multirow[b]{2}{*}{-0.8} \\
\hline at the age of $15-70$ & & & & & \\
\hline of working age & & 71.4 & 72.4 & 69.1 & -3.3 \\
\hline
\end{tabular}

Source: Calculated by data Публікаиія документів Державної служби статистики

України: [Електронний ресурс]. - Режим доступу: http:// ukrstat.org/uk/ operativ2015.

The level of economic activity in the population of working age came to $65,5 \%$ in 2014 , in rural areas $-62 \%$. Accordingly, the unemployment rate in rural areas has reached the critical level $-10.2 \%$, but the level of economic inactivity is 3,3 percentage points higher than in cities.

There is a positive but uneven dynamics of registered unemployed people according to place of residence. If in 2000 the ratio between the city unemployed and rural was of 3:1 (and it was explained by the corresponding population size), then in 2014 the number of the registered unemployed in cities and rural areas became equal - despite the fact that the number of rural population decreased (figure 1). 


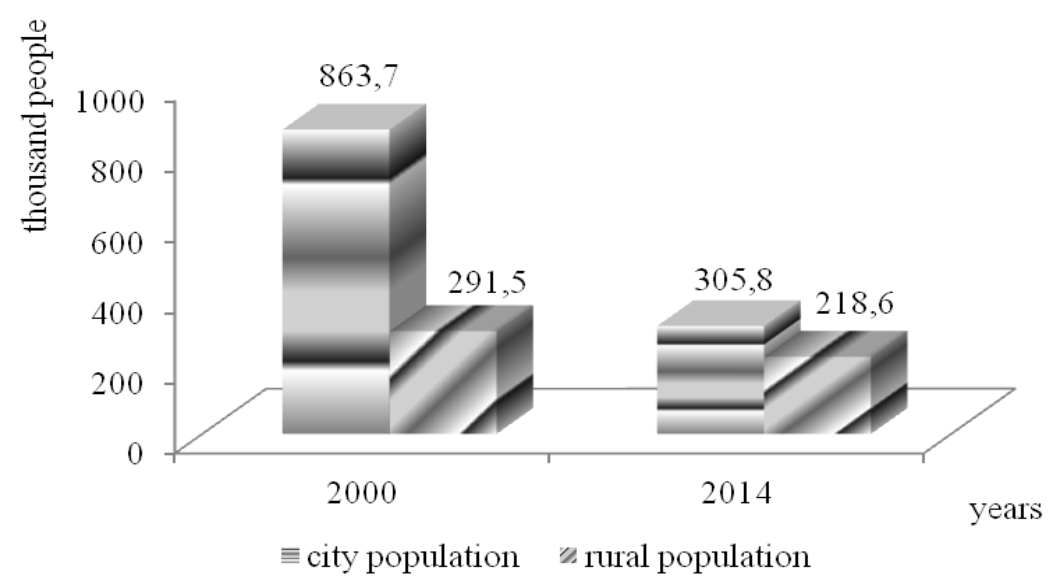

Figure 1. The dynamics of the number of the registered unemployed according to place of residence in Ukraine, 2000-2014, thousand people

Source: Calculated by data Публікаиія документів Державної служби статистики України: [Електронний ресурс]. - Режим доступу: http:// ukrstat.org/uk/ operativ2015.

The given statistics confirm higher competitiveness of the labour force of city dwellers and their possibility of job placement.

In marketing research of the labour market, aiming to provide an agrarian business with highly-qualified personnel with corresponding social and psychological qualities, segmentation of the labour market takes place that will allow to divide the research object in segments. Division of the labour market in closed sectors according to place of residence also points at problems of the rural employment, especially in youth (table 2 ).

According to the statistical data, the highest level of an economic activity of the urban population is observed at the age of 35-49 - almost $86 \%$, the rural one $82 \%$. There is a substantial difference between the unemployment rate of the urban and rural youth. If at the age of 25-29 the number of the city unemployed comes to $10.4 \%$, in the rural area $13.1 \%$ of the youth of the same age can't find employment.

The youth unemployment has its peculiarities - somebody is looking for a job for the first time after study, somebody doesn't carry a load and becomes unemployed, some part of youth changes views about the gotten profession. A young person chooses a profession at the age of 17-18, and the characteristic criteria in this case are preferences and finances of parents. Understandably, rural men, who know the worth of an agrarian work, want their children to study in cities to get medical, economic or legal education. If not every graduate, then at least a vast majority of them dream about the job that wouldn't be hard and dirty. They want their job to be well-paid and interesting as far as possible. It is not hard to assume that there are much less such positions than those who wish to hold them, particularly in agriculture. 
Table 2. The level of economic activity of population of Ukraine by age groups and according to place of residence in 2014

\begin{tabular}{|c|c|c|c|c|c|c|c|c|c|}
\hline \multirow{2}{*}{$\begin{array}{l}\text { Groups of } \\
\text { population }\end{array}$} & \multirow{2}{*}{ Total } & \multicolumn{7}{|c|}{ including by age groups, years old } & \multirow{2}{*}{$\begin{array}{l}\text { Of } \\
\text { working } \\
\text { age }\end{array}$} \\
\hline & & 15-24 & 25-29 & 30-34 & 35-39 & 40-49 & $50-59$ & $60-70$ & \\
\hline \multicolumn{10}{|c|}{$\begin{array}{l}\text { The level of economic activity of population, } \\
\text { on the average over a period, in \% to the total number of population of corresponding } \\
\text { age group }\end{array}$} \\
\hline $\begin{array}{l}\text { All } \\
\text { population }\end{array}$ & 62.4 & 38.4 & 80.5 & 82.6 & 84.8 & 84.6 & 63.2 & 15.5 & 71.4 \\
\hline $\begin{array}{l}\text { urban } \\
\text { settlement }\end{array}$ & 62.6 & 37.0 & 82.8 & 84.3 & 85.9 & 85.6 & 62.5 & 12.5 & 72.4 \\
\hline rural area & 61.8 & 41.3 & 75.0 & 77.3 & 82.0 & 82.4 & 64.8 & 22.9 & 69.1 \\
\hline \multicolumn{10}{|c|}{$\begin{array}{l}\text { The level of employment of population, on the average over a period, } \\
\text { in \% to the total number of population of corresponding age group }\end{array}$} \\
\hline $\begin{array}{l}\text { All } \\
\text { population }\end{array}$ & 56.6 & 29.5 & 71.6 & 74.9 & 77.9 & 78.4 & 59.4 & 15.5 & 64.5 \\
\hline $\begin{array}{l}\text { urban } \\
\text { settlement }\end{array}$ & 56.9 & 28.4 & 74.2 & 76.6 & 78.9 & 79.3 & 58.6 & 12.5 & 65.5 \\
\hline rural area & 55.9 & 31.8 & 65.2 & 69.8 & 75.4 & 76.6 & 61.2 & 22.9 & 62.0 \\
\hline \multicolumn{10}{|c|}{$\begin{array}{l}\text { The level of unemployment of population (by the methodology of ILO), } \\
\text { on the average over a period, } \\
\text { in } \% \text { to the total number of population of corresponding age group }\end{array}$} \\
\hline $\begin{array}{l}\text { All } \\
\text { population }\end{array}$ & 9.3 & 23.1 & 11.1 & 9.3 & 8.1 & 7.3 & 6.0 & 0.1 & 9.7 \\
\hline $\begin{array}{l}\text { urban } \\
\text { settlement }\end{array}$ & 9.2 & 23.2 & 10.4 & 9.1 & 8.2 & 7.4 & 6.2 & 0.1 & 9.5 \\
\hline rural area & 9.5 & 23.1 & 13.1 & 9.7 & 8.0 & 7.1 & 5.6 & 0.0 & 10.2 \\
\hline
\end{tabular}

Source: Calculated by data Публікачія документів Державної служби статистики

Украйни: [Електронний ресурс]. - Режим доступу: http:// ukrstat.org/uk/ operativ2015.

With the aim of functioning of the system of provision of professional information to the public including pupils of general education establishments, The State Employment Centre of the Ministry of Social Policy of Ukraine developed the innovation project "Vocational-oriented terminal" (2008) focused on the provision of availability, mobility, flexibility and attractiveness of vocational-oriented services for youth. The given project has been supported by the Ministry of Education and Science of Ukraine (Профорієнтаиійний термінал державної служби зайнятості: [Електронний ресурс]. - Режим доступу: http://versii.com/news/238981.).

Schoolchildren learn that there are more professions than only a lawyer and an economist! The terminal helps to understand the diversity of available specialties and identify which of them are demanded in Ukraine today. This device is unequalled in the world. Ukraine became a pioneer suggested this project, the main purpose of which is to approach a school leaver to native production realities.

No doubt, a great problem of labour market performance in our country is the activity of employment agencies, and there are some consulting firms specializing 
in recruitment and employment that can be found in the Internet and facilitate planning and career development for a certain payment. However, a rural dweller acts on his own authority in the labour market. That's why the mastery of personal marketing methods is an essential prerequisite of a successful career. The right career choice depends on the objective assessment of professional vocations and the real potential, the proper examination of labour market conditions, real possibilities of getting education, reeducation and skill improvement. Marketing in the labour sphere as in other spheres enables a worker to correct his labour power and sell labour services, taking into account conditions of the labour market and its laws. The application of marketing allows an applicant to identify the product demand, to advertise and distribute goods (to make self-presentation in a way to interest an employer, to get favorable conditions of work and payment) and to satisfy the buyer's needs in the best possible manner (the performance of duties to the best advantage, the consolidation at this job and succeeding in it).

The final objective of marketing research is the development of the corresponding strategy which combines and coordinates actions in the sector of employment. In personal marketing it is important to establish an employment strategy, and the final result of this strategy is optimal working conditions and fair wages.

Profits of rural dwellers, particularly in the form of wages, but not income of their own farming, are generalizing indicators of the standard of their well-being, the social protection in rural areas and the efficiency of state regulation of social and labour relations. The studies show that the level of payment for work of employees of different spheres in our country is not identical - the highest salaries are received in industry, financial institutions as well as a service sector. The lowest salaries are typical for agricultural workers. It only goes to show the fact why youth doesn't want to be employed in agriculture. Obviously, workers are interested in increasing their profits due to both increasing a labour power in the labour market and making greater efforts for receiving higher salaries. In 2014 the highest nominal average monthly salary was received by workers of the financial sphere $-7,020 \mathrm{hrn}$., in agriculture it was 2,476 hrn. which is 2,8 times lower than in financial institutions and $29 \%$ lower than on the national average (table 3 ).

Maximum wages are not limited now, but the Statute of International Labour Organization requires the equal pay for the equal work. In Ukraine, this principle is much violated. The equal work is paid unequally in branches, enterprises and organizations of all forms of ownership with different financial and economic status. The excessive differentiation of earnings is unjustified by neither requirements of an economic expediency nor an ordinary human justice.

Nowadays Government Employment Services are improving in completely new format - focus has been shifted from regulation of the current situation in the labour market to prevention of unemployment, in particular youth one. In its turn, an agrarian business should be involved in the solution of social and labour problems in rural areas, but not to "shift" overcoming the rural unemployment upon Government Employment Services. Introducing "Marketing 3.0", an agrarian business can influence an intellect, a heart and a soul of rural dwellers, recognize 
their anxieties and wishes, improve rural areas, perhaps, even make it an ideal place for living. The sense of marketing 3.0 is to make a strong image of an agrarian business in which it is safe, prestigious and beneficial to work. It can be done by recognizing a unique individual and supporting him or her sincerely.

Table 3. The dynamics of average monthly earnings by main types of economic activities in Ukraine, 2010-2014, hrn.

\begin{tabular}{|l|c|c|c|c|c|c|}
\hline \multicolumn{1}{|c|}{ The type of activity } & $\mathbf{2 0 1 0}$ & $\mathbf{2 0 1 1}$ & $\mathbf{2 0 1 2}$ & $\mathbf{2 0 1 3}$ & $\mathbf{2 0 1 4}$ & $\begin{array}{c}\mathbf{2 0 1 4} \\
\text { in \% till } \\
\mathbf{2 0 1 0}\end{array}$ \\
\hline Total & 2,250 & 2,648 & 3,041 & 3,282 & 3,480 & 154.7 \\
\hline Agriculture & 1,422 & 1,786 & 2,024 & 2,269 & 2,476 & 174.1 \\
\hline Industry & 2,578 & 3,119 & 3,497 & 3,774 & 3,988 & 154.7 \\
\hline Building & 1,777 & 2,294 & 2,543 & 2,727 & 2,860 & 160.9 \\
\hline Whole and retail trade & 1,898 & 2,371 & 2,739 & 3,049 & 3,439 & 181.2 \\
\hline $\begin{array}{l}\text { Transport,warehousing, } \\
\text { mailing and courier } \\
\text { activities }\end{array}$ & 2,648 & 3,061 & 3,405 & 3,582 & 3,768 & 142.3 \\
\hline $\begin{array}{l}\text { Information and } \\
\text { telecommunication }\end{array}$ & 3,185 & 3,705 & 4,360 & 4,659 & 5,176 & 162.5 \\
\hline $\begin{array}{l}\text { Financial and insurance } \\
\text { activities }\end{array}$ & 4,695 & 5,433 & 6,077 & 6,326 & 7,020 & 149.5 \\
\hline $\begin{array}{l}\text { Government control and } \\
\text { defense }\end{array}$ & 2,735 & 3,049 & 3,432 & 3,719 & 3,817 & 139.6 \\
\hline Education & 1,884 & 2,077 & 2,532 & 2,696 & 2,745 & 145.7 \\
\hline Health protection & 1,616 & 1,762 & 2,186 & 2,351 & 2,441 & 151.1 \\
\hline $\begin{array}{l}\text { Art, sport, entertainment, } \\
\text { and recreation }\end{array}$ & 2,129 & 2,394 & 3,017 & 3,343 & 3,626 & 170.3 \\
\hline
\end{tabular}

Source: Calculated by data Публікаиія документів Державної служби статистики

України: [Електронний ресурс]. - Режим доступу: http:// ukrstat.org/uk/ operativ2015.

Marketing 3.0 is also marketing of the sense hidden in corporative missions, vision and values. Having defined the term in such way, we want to give it the role of an important player in developing the strategic future of an agrarian business. Marketing cannot be understood any more as the sale and the use of different tools in order to create a market. Henceforth, marketing should be considered as a high hope of business (an employer) on generating confidence of rural population on basis of: the promise of transformations, convincing stories, the attraction of youth; the cooperation based on values (to be better, different, alter life for the better); the decreasing poverty rate by financial stimulation.

For the agrarian business which is oriented on "Marketing 3.0" any gap between marketing and values is unacceptable (table 4). 
Table 4. The comparison of three marketing variants - 1.0, 2.0 i 3.0

\begin{tabular}{|c|c|c|c|}
\hline Specifications & $\begin{array}{c}\text { Marketing } 1.0- \\
\text { product orientation }\end{array}$ & $\begin{array}{c}\text { Marketing } 2.0- \\
\text { consumer } \\
\text { orientation }\end{array}$ & $\begin{array}{c}\text { Marketing } 3.0- \\
\text { values orientation }\end{array}$ \\
\hline Purpose & To sell products & $\begin{array}{c}\text { To satisfy the needs } \\
\text { and retain the } \\
\text { consumer }\end{array}$ & $\begin{array}{l}\text { To make the world } \\
\text { a better place }\end{array}$ \\
\hline Mobile power & $\begin{array}{l}\text { Industrial } \\
\text { revolution }\end{array}$ & $\begin{array}{l}\text { Information } \\
\text { technology }\end{array}$ & $\begin{array}{c}\text { Technology of the } \\
\text { new wave }\end{array}$ \\
\hline $\begin{array}{l}\text { How companies } \\
\text { consider market }\end{array}$ & $\begin{array}{c}\text { Mass-market } \\
\text { customers with } \\
\text { physiological needs }\end{array}$ & $\begin{array}{l}\text { Informed customers } \\
\text { with their thoughts } \\
\text { and emotions }\end{array}$ & Values \\
\hline Marketing concepts & $\begin{array}{l}\text { Focus on product } \\
\text { specifications }\end{array}$ & $\begin{array}{c}\text { Positioning of an } \\
\text { enterprise and } \\
\text { product }\end{array}$ & $\begin{array}{c}\text { Mission, vision and } \\
\text { values of a } \\
\text { company }\end{array}$ \\
\hline User value & Functional & $\begin{array}{l}\text { Functional and } \\
\text { emotional }\end{array}$ & $\begin{array}{c}\text { Functional, } \\
\text { emotional and } \\
\text { spiritual } \\
\end{array}$ \\
\hline $\begin{array}{c}\text { Interaction with } \\
\text { customers }\end{array}$ & "One with many" & "One with one" & $\begin{array}{l}\text { "Cooperation of } \\
\text { many with many" }\end{array}$ \\
\hline
\end{tabular}

Source: Own elaboration.

There is a close link between marketing 3.0 and millennium goals. "Millennium goals" are eight quantitative objectives that were agreed by 189 world leaders at UN Millenium Summit in September 2000 (Котлер, Картаджайя 2012, p. 240).

1. To end poverty and hunger.

2. To provide primary education.

3. To achieve gender equality.

4. To reduce children's mortality.

5. To improve maternal health.

6. To defeat HIV/AIDS, malaria and other diseases.

7. To introduce an ecological responsibility.

8. To establish a global partnership for development.

Marketing 3.0 concepts in the labour sphere work to achieve "Millenium goals":

- Concept 1: to love workers, customers and respect competitors.

- Concept 2: to be alive to changes and be ready to change.

- Concept 3: to save the name and show your identity clearly.

- Concept 4: always to offer good well-priced products.

- Concept 5: always to be available to customers and spread good news.

- Concept 6: to attract your customers, retain them, promote business development.

- Concept 7: regardless of kind of a business, to consider that you work in services sector.

- Concept 8: constantly to improve a business on criteria of quality, cost effectiveness and promptitude of delivery.

- Concept 9: to gather all significant information, but to make the final decision wisely and carefully. 
In order to introduce a good job into a corporate culture of an agrarian business, and forever, it is better to include it in the mission, the vision and values of the business. To begin with the mission is the first lesson that a business can learn in successful noncommercial organizations. A successful business starts planning with not financial returns, but plans of undertaking its mission. And a financial success is the result of such approach (table 5).

Table 5. "Matrix of values" of marketing 3.0

\begin{tabular}{|c|c|c|c|c|}
\hline \multirow{2}{*}{ Values } & \multicolumn{3}{c|}{ Person } \\
\cline { 2 - 5 } & Intellect & Heart & Soul \\
\hline \multirow{3}{*}{$\begin{array}{c}\text { Mission } \\
\text { (what for?) }\end{array}$} & $\begin{array}{c}\text { To provide } \\
\text { satisfaction }\end{array}$ & To realize ambitions & $\begin{array}{c}\text { To express } \\
\text { sympathy }\end{array}$ \\
\cline { 2 - 5 } & $\begin{array}{c}\text { Vision } \\
\text { (what?) }\end{array}$ & Profitability & Return & Responsibility \\
\cline { 2 - 5 } & $\begin{array}{c}\text { Values } \\
\text { (how?) }\end{array}$ & To be better & To be different & $\begin{array}{c}\text { Alter life for the } \\
\text { better }\end{array}$ \\
\hline
\end{tabular}

Source: Own elaboration.

Vision can be defined as a picture of the desirable future situation of a business. Vision explains what a business strives for and what wants to achieve. In order to formulate vision, an agrarian business should create the picture of its future on the basis of existing definition of a corporate mission. The mission, the vision and values form the matrix in which mentioned efforts of the business are oriented on an intellect, a heart and a soul of its existing and future employees. Hence, marketing 3.0 is the time of changes! Now we can give the decisive answer - "yes" to the question, "Can an agrarian business for which the major concern is a person be also profitable?' In fact, it has been found that marketing 3.0 is a personal involvement and a desire to help. Marketing 3.0 is an opportunity to share an emotional warmth, help financially those who need it. Somebody can give bread, somebody - money, somebody - pay attention. Any help is important, and it is hardly possible to identify which is bigger, which is smaller. By the way, concerning charity, a multi-millionaire Pole Hetty said, 'The best kind of charity that I know is the art to find money on wages of employees'. The australian millionaire said, 'The best way to help poor people is not to become one of them (Райс, Траут 2005, p. 160).

Marketing 3.0 is servicing people. By means of Marketing 3.0 an agrarian business can improve the situation on the labour market of rural areas:

1) to reduce unemployment level of rural population;

2) to raise profits of rural dwellers;

3) to minimize urbanism;

4) to decrease the level of a social strain of rural dwellers;

5) to raise the level of a general culture of rural population. 
The agrarian business oriented on "Marketing 3.0" can alter life of people for the better also with the help of charity focused on the solution of either its own or public problems.

\section{Conclusions}

The studies of labour market conditions, the identification of demand elasticity and labour supply, the level of labour productivity, the analytical and prediction calculations are essential in developing effective programs of employment and unemployment reduction. Marketing research of the social and labour sphere is one of the most important tools of the development of the reasonable state social policy while marketing 3.0 is a strategic future of the agrarian business hidden in a corporate mission, vision and values of improvement in the social and labour sphere.

The development of the strategy concerning the solution of problems in the social and labour sphere in rural areas should be based on the overall assessment of tendencies in labour market formation and the identification of principal directions of marketing 3.0. In our opinion, the main ways of unemployment reduction in rural areas are: adopting the active demographic policy; housing for youth; providing an employment; the development of business activity and farming; the involvement of population in self-employment; arranging wage earning public work; the introduction of flexible working hours; the occupational guidance and psychological support of population, in particular youth; training, retraining and personnel development; motivating labour activity.

It will take plenty of time for "Marketing 3.0" of an agrarian business to show its potential and be used on a par with other tools in the labour market. This is because according to regulations of marketing 3.0 of an agrarian business it is required: to consider the rural population as a strategic base point, to see in it not only workers, but people with their needs and wishes; to inform every employee about your corporate vision, mission and values; to assist in solving global social and labour problems of rural areas (a low standard of living, poverty) and to use in this case your business model focused on a person.

Despite all difficulties, we hope that a number of agrarian enterprises and rural dwellers who will include the Internet marketing in the list of tools in use will be gradually increasing, and Ukrainian rural areas will become an ideal place for living.

\section{References}

1. Brzozowska A., Kalinichenko A., Kabus J., Analyzing the strategies used in media discourse management, J. Eastern-European Journal of Enterprise Technologies, 2015, Vol 5, No 3(77), pp. 10-14. DOI: http://dx.doi.org/10.15587/1729-4061.2015.51397.

2. Грішнова О.А., Економіка праиі та соиіально-трудові відносини: [підручник]. - [3-те вид., випр. і доп.] - К.: Т-во «Знання», КОО, 2007, p.559.

3. Ковбаско О.М., Закордонний досвід підвищення кваліфікаиії керівників підрозділів служб зайнятості // Сучасні проблеми маркетингу ринку праці: [матеріали Міжнародної науково-практичної конференції, (Київ, 25 жовтня 2012)] / редкол.: О.Ю. Вілкова, Л.Г. Новаш, М.В.Судаков. - К.: ІПК ДСЗУ, 2012, pp. 89-90. 
4. Котлер Ф., Картаджайя Х., Сетиаван И., 3.0: от продуктов к потребителям и далее к человеческой душе [перевод с англ. А. Заякина]. - М.: Эксмо, 2012, р. 240.

5. Легомінова С.В., Маркетинг ринку праиі (методологія досліджень) [електронний peсурс] - Режим доступу: http://www.lib.ua-ru.net/diss/cont/26468.html.

6. Онікієнко В.В., Ринок праці та соиіальний захист населення України: ретроаналіз, проблеми, иляхи вирішення: [науково-аналітична монографія]. - К.: Ін-т демографії та соціальних досліджень імені М.В. Птухи НАН України, 2013, р. 456.

7. Профорієнтаиійний термінал державної служби зайнятості: [Електронний ресурс]. - Режим доступу: http://versii.com/news/238981.

8. Публікація документів Державної служби статистики України: [Електронний peсурс]. - Режим доступу: http:// ukrstat.org/uk/operativ2015.

9. Райс Э., Траут Д. 22 непреложных закона маркетинга: Нарушайте их на свой страх и риск!-M: ACT, 2005, p. 160.

\section{ROLA MARKETINGU W ROZWIAZZYWANIU PROBLEMÓW W SFERZE SPOŁECZNEJ I PRACY NA OBSZARACH WIEJSKICH}

Streszczenie: W opracowaniu zbadano istotę teoretyczną "Marketingu 3.0”, konieczność i skuteczność wykorzystania go do regulacji zatrudnienia na obszarach wiejskich i zmniejszenia bezrobocia. Dokonano analizy działalności gospodarczej populacji według grup wiekowych i miejsca zamieszkania, oficjalnego wskaźnika bezrobocia na obszarach wiejskich oraz $\mathrm{w}$ miastach jak również dynamiki średnich zarobków miesięcznych w podstawowych typach działalności gospodarczej na Ukrainie w celu określenia mechanizmu funkcjonowania rynku pracy na obszarach wiejskich. Zidentyfikowano główne przyczyny bezrobocia wśród młodych na obszarach wiejskich. Dokonano analizy działalności urzędów pracy. Udowodniono, że marketing 3.0 stanowi przyszłość strategiczną działalności rolniczej w kontekście poprawy sytuacji w sferze społecznej i pracy.

Słowa kluczowe: marketing 3.0, badania marketingowe, rynek pracy, stosunki społeczne i pracy, obszary wiejskie, zatrudnienie, bezrobocie 